\title{
MANAJEMEN PEMASARAN DAN MANAJEMEN USAHA BAGI KELOMPOK WANITA TANI PEMBUAT TELUR ASIN DAN TELUR ASIN ASAP DI KABUPATEN HULU SUNGAI TENGAH
}

\section{(The Marketing And Effort Management For The Women's Farmer Group Making Salted Eggs And Smoke-Salted Eggs In The Regency Of Hulu Sungai Tengah)}

\section{Gusti Marliani, Ernawati dan Khairiyahtul Anwar}

\author{
Fakultas Ekonomi \\ Universitas Achmad Yani Banjarmasin Kalimantan Selatan \\ Jl. Ahmad Yani Km 5,5 Komplek Stadion Lambung Mangkurat Banjarmasin, 70249
}

e-mail : yayana feuvaya@yahoo.co.id dan gustimarliani@uay.ac.id

Abstract

Eggs resulting from cattle used for nutritional consumption and sold as the family income. To make eggs durable, group of farmers women change it into salted egg and smoke salted egg (intalu jaruk). Ipteks program for communities in particular groups of farmers women salted duck egg smoke maker aims to increase competence in the form of knowledge, skills and abilities farmers of women in solving problems in the field of business management and marketing management. An increase in marketing management of marketing strategies, making leaflets, a signboard, packaging and brands. An increase in business management of making the profile and structure partner organizations.

This event is held for four months since may and Agust 2016. The targets for the event are groups of farmers women maker eggs duck salted smoke as many as 2 groups that is groups of farmers women melati village kalibaru subdistrick batu benawa and groups of women farmers mufakat village hilir banua kecamatan pandawan kabupaten Hulu Sungai Tengah South Kalimantan

Application of science and technology for the is expected to adopted by a group partner in their entirety with direct involvement between teams devotion with groups of women farmers melati and groups of women farmers mufakat maker salted egg and salted egg smoke. The implementation of the program devotion it is developed to strategically with focus groups discussion with a partner, training, counseling , technical assistance, evaluation and monitoring of the program the application of science and technology

The results of this activity is increasing knowledge , ability and skill in the management of marketing and business management. In addition it products of leaflets or brochures, a signboard, packaging and brands, profile business and structure organization.

Keywood : salted egg, salted smoke Egg, marketing, business management

Abstrak

Telur yang dihasilkan dari ternak digunakan untuk konsumsi pemenuhan gizi dan dijual sebagai penghasilan keluarga. Supaya telur tahan lama oleh ibu-ibu kelompok wanita tani dibuatlah telur menjadi telur asin dan telur asin asap (intalu jaruk). Program Ipteks bagi Masyarakat khususnya Kelompok Wanita Tani pembuat telur asin dan telur asin asap ini bertujuan untuk meningkatkan kompetensi berupa pengetahuan, kemampuan dan ketrampilan wanita tani dalam memecahkan masalah di bidang manajemen pemasaran dan manajemen usaha. Peningkatan manajemen pemasaran berupa strategi pemasaran, pembuatan leaflet, papan nama, kemasan dan merk. Peningkatan manajemen usaha berupa pembuatan profil dan struktur organisasi mitra.

Kegiatan ini dilaksanakan selama 4 bulan sejak Mei sampai Agustus 2016. Sasaran dari kegiatan in adalah kelompok wanita tani pembuat telur asin dan telur asin asap sebanyak 2 kelompok yaitu Kelompok Wanita Tani Melati Desa Kalibaru Kecamatan Batu Benawa dan Kelompok Wanita Tani Mufakat Desa Hilir Banua Kecamatan Pandawan Kabupaten Hulu Sungai Tengah Kalimantan Selatan.

Penerapan Iptek bagi masyarakat ini diharapkan dapat diadopsi oleh kelompok mitra secara utuh dengan keterlibatan langsung antara tim pengabdian dengan kelompok wanita tani melati dan kelompok wanita tani mufakat pembuat telur asin dan telur asin asap. Pelaksanaan program pengabdian ini disusun secara strategis dengan melakukan diskusi kelompok kerja (FGD) dengan mitra, pelatihan, penyuluhan, pendampingan teknis, evaluasi dan monitoring program penerapan iptek tersebut.

Hasil dari kegiatan ini adalah meningkatnya pengetahuan, kemampuan dan ketrampilan dalam manajemen pemasaran dan manajemen usaha. Selain itu dihasilkannya produk berupa leaflet atau brosur, papan nama, kemasan dan merk, profil usaha dan struktur organisasi.

Kata Kunci : Telur Asin, Telur Asin Asap, Pemasaran, Manajemen Usaha. 


\section{PENDAHULUAN}

Telur merupakan hasil ternak yang memiliki andil besar dalam mengatasi masalah gizi yang terjadi dalam masyarakat. Hal ini dimungkinkan karena telur sarat akan zat gizi yang diperlukan untuk kesehatan.

Beternak ayam dan bebek banyak dilakukan oleh masyarakat khususnya petani sebagai pekerjaan tambahan. Hasil ternak ayam dan bebek berupa telur merupakan produk yang dapat memenuhi kebutuhan akan gizi dalam keluarga sedangkan sisa dari pemenuhan gizi tersebut telur juga bisa dijual sebagai penghasilan keluarga. Banyaknya telur yang dihasilkan biasanya langsung dijual kepada konsumen, hal ini menyebabkan harga jual yang rendah karena telur mempunyai daya tahan yang tidak lama sehingga peternak tidak bisa menunggu harga menjadi lebih tinggi.

Supaya telur tahan lama dan dapat meningkatkan harga jual dari telur tersebut oleh ibu-ibu kelompok wanita tani dibuatlah telur menjadi telur asin dan telur asin asap. Telur asin dan telur asin asap disebut intalu jaruk (Bahasa Banjar) yang banyak dibuat berasal dari telur bebek atau sering disebut intalu itik oleh orang Kalimantan Selatan. Teknik mengasinkan telur telah ada dilakukan sejak dahulu. Telur asin dibuat dengan tujuan agar mempunyai daya tahan telur yang lama, dapat disimpan, dapat langsung dimakan konsumen, mempunyai cita rasa dan mempunyai daya jual yang tinggi.

Adapun kelebihan telur bebek dibandingkan dengan telur yang lainnya adalah telur bebek memiliki pori pori kulit yang lebih besar, sehingga sangat baik untuk diolah menjadi telur asin dan telur asin asap. Telur asin asap merupakan telur bebek yang dibuat dari telur asin kemudian dimasak dengan cara pengasapan dingin.

Proses pengasapan dapat memperpanjang masa simpan telur asin sampai 1 bulan. Telur asin asap pembuatannya serupa dengan pembuatan telur asin, yang membedakannya hanyalah proses pengasapan. Selain memperpanjang masa simpan, proses pengasapan pada telur asin asap berfungsi untuk mengeluarkan tekstur kulit yang menarik, bau tidak amis serta aroma khas asap yang menggugah selera. Sistem pengasapan yang digunakan adalah pengasapan dingin, dengan suhu sekitar $30-40^{\circ} \mathrm{C}$.

Bahan bakar yang bisa digunakan dalam pengasapan adalah kayu bakar, batok kelapa, sekam serta bahan bakar lain sebagai alternatif adalah serbuk gergaji, serutan kayu, tempurung, sabut kelapa dan sebagainya. Sabut kelapa merupakan hasil limbah pertanian yang murah dan mudah didapatkan, dan belum ada pemanfaatan yang maksimal serta ketersediaannya sangat melimpah di daerah Kalimantan Selatan. Pengasapan telur asin asap menggunakan waktu 4 jam.

Kalimantan Selatan terdiri dari 13 Kabupaten/kota. Daerah-daerah yang merupakan sentra pembuat telur bebek asin di Kalimantan Selatan adalah Kabupaten Banjar, Kabupaten Tanah Laut, Kabupaten Tapin, Kabupaten Hulu Sungai Selatan, Kabupaten Hulu Sungai Tengah, Kabupaten Hulu Sungai Utara dan Kabupaten Tabalong. Untuk Kabupaten Hulu Sungai Tengah pembuat telur bebek asin banyak dikerjakan oleh kumpulan ibu-ibu rumah tangga yang berada di 
Desa Kalibaru Kecamatan Batu Benawa dan Desa Hilir Banua Kecamatan Pandawan.

Di Kabupaten Hulu Sungai Tengah, masyarakat petani selain bertani mereka memelihara ternak ayam dan bebek. Hasil telur yang banyak supaya dapat disimpan lama maka dibuatlah telur asin, seperti di Kecamatan Batu Benawa Desa Kalibaru terdapat kumpulan ibu-ibu rumah tangga yang tergabung dalam kelompok Wanita Tani Melati pembuat telur bebek asin asap yang anggotanya sebanyak 21 orang. Sedangkan di Kecamatan Pandawan Desa Hilir Banua terdapat 1 (satu) Kelompok Wanita Tani yaitu Kelompok Wanita Tani Mufakat yang anggotanya sebanyak 17 orang pembuat telur bebek asin.

Berdasarkan hasil penelitian (Marliani dan Ernawati, 2015) Pembuatan telur asin dan telur asin asap di daerah tersebut mampu meningkatkan pendapatan keluarga sehingga terciptanya kesejahteraan ekonomi keluarga, tetapi pembuatan telur asin dan telur asin asap ini masih merupakan pekerjaan tambahan atau sampingan dari ibu-ibu tani. Kebanyakan pekerjaan utamanya adalah petani dan berkebun.

Selain itu dari segi produk dan pemasaran masih sederhana. Produk telur asin dan telur asin asap hanya ada satu rasa yaitu rasa asin atau original belum ada rasa yang lain seperti rasa udang, rasa kepiting dan rasa ikan yang diproduk oleh masyarakat kampong bebek di Sidoarjo Jawa Timur. Pada segi pemasaran belum ada distribusi yang jelas, produksi banyak berdasarkan pesanan. Belum ada promosi dan kemasan yang baik, produk telur hanya diberi tok stempel saja.

Pemasaran sangat penting bagi penjual menurut Kotler dan Keller (2009 : 5) pemasaran adalah sebuah proses kemasyarakatan dimana individu dan kelompok memperoleh apa yang mereka butuhkan dan inginkan dengan menciptakan, menawarkan, dan secara bebas mempertukarkan produk dan jasa yang bernilai dengan orang lain. Selanjutnya menurut Lupiyoadi dan Hamdani (2008 : 70) bauran pemasaran mencakup produk, harga, tempat dan promosi.

Kegiatan pembuat telur bebek asin dan telur bebek asin asap oleh ibu-ibu tani harus terus digerakan dan dikembangkan dengan menerapkan strategi pemasaran dan manajemen usaha karena kegiatan pembuat telur asin ini dapat menyerap tenaga kerja khususnya ibu-ibu rumah tangga dan dapat menambah penghasilan sehingga dapat meningkatkan kesejahteraan keluarga.

\section{METODE}

Untuk mengkaji permasalahan pokok yang dihadapi kelompok mitra dilakukan observasi dan disusun dalam matrik permasalahan dan prioritas pemecahan masalah kelompok dapat dilhat pada tabel 1 :

Pada penerapatan Iptek ini kepada mitra kelompok dibuatlah program kerja sebagai berikut : a) Diskusi kelompok kerja / Focus group discution (FGD) tentang pemasalahan dan alternatif masalah. b) Penyuluhan tentang strategi pemasaran yang meliputi produk, promosi, distribusi dan harga dari produk telur bebek asin dan telur bebek asin asap. c) Pendampingan pembuatan leaflet, papan nama, kemasan dan merk supaya menarik konsumen. d) Pelatihan tentang manajemen usaha. e) Pendampingan pembuatan profil kelompok dan organisasi kelompok. 


\section{HASIL DAN PEMBAHASAN}

Berdasarkan permasalahan yang telah diidentifikasi pada kelompok mitra pembuat telur asin dan telur asin asap dan disesuaikan dengan kepakaran yang dimiliki oleh dosen Universitas Achmad Yani Banjarmasin, maka didapatlah solusi pemecahan masalah tersebut dengan diberikannya penyuluhan, pelatihan dan pendampingan penerapan dari materi-materi yang diberikan kepada mitra sehingga hasil yang dicapai dapat dilihat dalam tabel 2 :

Berdasarkan tabel diatas maka dapat dijabarkan bahwa hasil yang dicapai dari kegiatan Ipteks Bagi Masyarakat ini adalah meningkatnya wawasan, pengetahuan dan ketrampilan kelompok wanita tani melati dan kelompok wanita tani mufakat dalam aspek pemasaran sehingga mempunyai strategi pemasaran yang lebih baik, adanya promosi dengan baik karena mempunyai brosur dan papan nama. Kemasan produk yang lebih menarik dan dapat dibawa sebagai souvenir dengan aman.

Selain meningkatnya wawasan dan pengetahuan dari segi pemasaran, Ipteks Bagi Masyarakat ini juga dapat meningkatkan wawasan dan pengetahuan dalam manajemen usaha mitra yaitu dengan mempunyai struktur organisasi dan profil usaha organisasi mitra.

Tabel 1. Matrik Permasalahan dan Prioritas Pemecahan Masalah Mitra

\begin{tabular}{|c|c|c|c|}
\hline \multirow[b]{3}{*}{$\begin{array}{l}\text { Kebutuhan } \\
\text { masalah }\end{array}$} & \multirow[b]{3}{*}{ pemecahan } & \multicolumn{2}{|c|}{ Kondisi aktual permasalahan mitra } \\
\hline & & Sistem Pemasaran & Manajemen usaha \\
\hline & & $\begin{array}{l}\text { Memperluas pangsa pasar } \\
\text { dengan promosi berupa } \\
\text { leaflet, papan nama dan } \\
\text { perbaikan kemasan dan merk }\end{array}$ & $\begin{array}{l}\text { Kelompok mitra yang sudah ada dan } \\
\text { beranggotakan } 17 \text { orang sampai } 21 \text { orang } \\
\text { membuka kesempatan untuk dapat } \\
\text { memperbaiki manajemen usaha dengan } \\
\text { pembuatan profil dan struktur organisasi } \\
\text { mitra }\end{array}$ \\
\hline
\end{tabular}

Tabel 2 Hasil Yang Dicapai

\begin{tabular}{|c|c|c|}
\hline No. & Kegiatan Solusi Masalah & Hasil Yang Dicapai \\
\hline \multirow[t]{4}{*}{1} & Penyuluhan tentang strategi pemasaran. & $\begin{array}{l}\text { a. Sebanyak } 80 \% \text { ibu-ibu pembuat telur asin } \\
\text { yang mengikuti penyuluhan memahami } \\
\text { tentang strategi pemasaran. }\end{array}$ \\
\hline & $\begin{array}{l}\text { b. Pembuatan leaflet atau brosur untuk } \\
\text { memasarkan produk. }\end{array}$ & b. Leaflet dan brosur produk. \\
\hline & $\begin{array}{l}\text { c. Pembuatan papan nama untuk promosi } \\
\text { produk }\end{array}$ & c. Papan nama. \\
\hline & $\begin{array}{l}\text { d. Pembuatan merk dan kemasan produk yang } \\
\text { baik dan menarik }\end{array}$ & d. Kemasan dan merk produk. \\
\hline \multirow[t]{2}{*}{2} & a. Penyuluhan tentang manajemen usaha. & $\begin{array}{l}\text { a. Sebanyak } 80 \% \text { ibu-ibu pembuat telur asin } \\
\text { yang mengikuti pelatihan memahami tentang } \\
\text { manajemen usaha. }\end{array}$ \\
\hline & $\begin{array}{l}\text { b. Pembuatan } \\
\text { organisasi. }\end{array}$ & Profil UKM dan struktur organisasi. \\
\hline
\end{tabular}



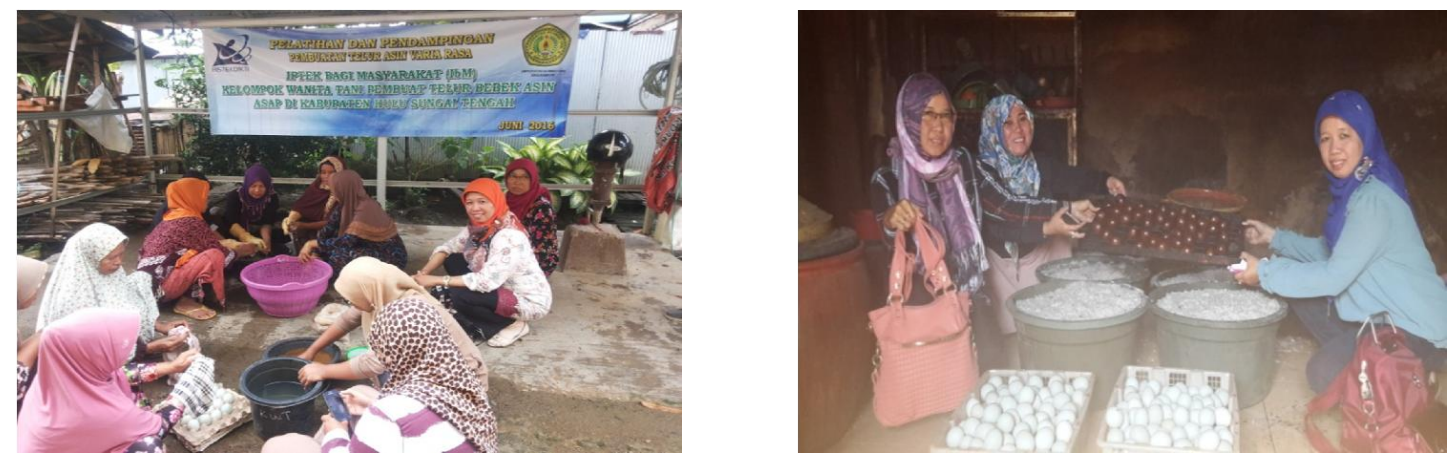

Gambar 1 : Proses Pembuatan Telor Asin
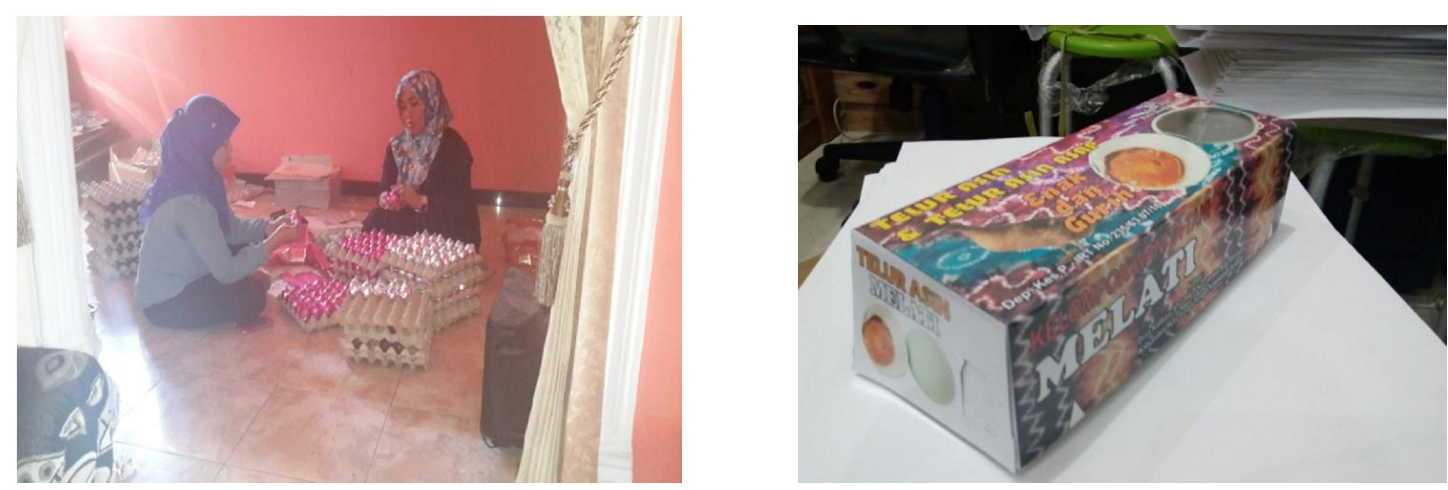

Gambar 2 : Hasil Telor Asin dan Packing Telor Asin

\section{SIMPULAN DAN SARAN}

\section{Simpulan}

1. Hasil yang dicapai dari kegiatan Ipteks Bagi Masyarakat ini adalah dapat meningkatkan wawasan, kemampuan dan ketrampilan kelompok wanita tani melati dan kelompok wanita tani mufakat dalam aspek pemasaran sehingga mempunyai strategi pemasaran yang lebih baik, adanya promosi yang baik, kemasan produk yang menarik. Selain itu meningkatnya manajemen usaha mitra dengan mempunyai struktur organisasi dan profil usaha mitra.

online : http://jurnal.umpalangkaraya.ac.id/ejurnal/pgbmu
2. Kegiatan penerapan Ipteks Bagi Masyarakat yang telah dilakukan ini secara keseluruhan mendapat tanggapan positif dari ibu-ibu kelompok wanita tani pembuat telur asin dan telur asin asap. Kelompok ibu-ibu juga antusias untuk mengembangkan usaha mereka lebih besar.

\section{Saran}

1. Diharapkan Kelompok wanita tani lebih banyak lagi mempunyai ternak bebek sehingga telur yang diproduksi lebih banyak dan tidak tergantung pada peternak lain.

2. Perlunya dukungan pemerintah dalam mengembangkan usaha pembuat telur asin 
dan telur asin asap ini dengan mempermudah prosedur pengolahan ijin usaha, mendapatkan IPRT dan label halal.

3. Perlunya bimbingan, penyuluhan dan pelatihan bagi ibu -ibu kelompok tani pembuat telur asin dan telur asin asap dalam bidang manajemen produksi, manajemen sumber daya manusia, manajemen keuangan dan teknologi informasi.

\section{UCAPAN TERIMAKASIH}

1. Kepada DRPM dikti yang telah memberikan bantuan dana sehingga kegiatan IbM ini dapat dilaksanakan dengan baik.

2. Kepada Kopertis Wilayah XI Kalimantan yang telah memberikan motivasi, arahan dan bantuan dalam prosedur pelaksanaan kegiatan.

3. Kepada Bapak Rektor Universitas Achmad Yani Banjarmasin yang telah mendukung kegiatan ini dengan memberikan fasilitas sarana dan prasarana yang diperlu.

4. Kepada DRPM dikti yang telah memberikan bantuan dana sehingga kegiatan IbM ini dapat dilaksanakan dengan baik.

5. Kepada Kopertis Wilayah XI Kalimantan yang telah memberikan motivasi, arahan dan bantuan dalam prosedur pelaksanaan kegiatan.

6. Kepada Bapak Rektor Universitas Achmad Yani Banjarmasin yang telah mendukung kegiatan ini dengan memberikan fasilitas sarana dan prasarana yang diperlu.

\section{DAFTAR PUSTAKA}

Aritonang. 1993. Aneka Olahan Telur. Agro Media. Bogor.

Gumay. 2009. Produk Telur Asin. Agro Media. Surabaya

Kotler dan Keller. 2009. Manajemen Pemasaran. Edisi 13. Jakarta : Erlangga.

Lupiyoadi, Rambat dan Hamdani. 2008. Manajemen Pemasaran Jasa, Edisi dua. Jakarta : Salemba Empat,

Marliani dan Ernawati. 2015. Sektor Informal Pengrajin Telur Asin Asap Terhadap Pendapatan Keluarga Kelompok Wanita Tani "Melati" di Desa Kalibaru Kecamatan Batu Benawa Kabupaten Hulu Sungai Tengah. Fakultas Ekonomi Universitas Achmad Yani Banjarmasi. 